\title{
Study of Bali cattle physiological parameters during sea transport on camara nusantara ships
}

\author{
Adam Kustiadi Nugraha*1), Rudi Afnan ${ }^{2)}$, Epi Taufik ${ }^{2)}$ and Aryani Sismin Satyaningtijas ${ }^{3)}$ \\ ${ }^{1)}$ Graduate Student of Animal Production Science and Technology, Faculty of Animal \\ Science, IPB University, Bogor, Indonesia, 16680 \\ ${ }^{2)}$ Department of Animal Production and Technology, Faculty of Animal Science, IPB \\ University, Bogor, Indonesia, 16680 \\ ${ }^{3)}$ Department of Anatomy, Physiology and Pharmacology, Faculty of Veterinary Medicine, \\ IPB University, Bogor, Indonesia, 16680
}

Submitted: 14 October 2019, Accepted: 21 November 2020

\begin{abstract}
There have never been specific research or study about cattle health during shipment using a Camara Nusantara ship as a mode of transportation. The objective of this study was to investigate the ship environment and physiological responses of cattle during transport from Tenau Port (Kupang) to Tanjung Priok Port (Jakarta) using Camara Nusantara 3 ship. The sample of 12 Bali cattle was determined using the purposive sampling total of 250 Bali cattle during transportation. Physiological parameters (including rectal temperature, respiratory rate, pulse rate) were used to evaluate the welfare status and stress level of animals, during the respective transport journeys. Transient changes in physiological parameters were found in the transported animals from day 2 to 4 relative to baseline levels, and the values were within the mild stress level of physiological range for the age of animals involved. There were significant differences $(\mathrm{P}<0.05)$ in rectal temperature, humidity, and temperature humidity index (THI). Using factorial Analysis of variance (ANOVA), there was an interaction between deck and day trip in the respiratory rate parameter. The cattle regained their initial normal range of physiological level and had slightly recovered by the time of their arrival on the $5^{\text {th }}$ day of the journey.
\end{abstract}

Keywords: Cattle physiology; Cattle ship; Cattle transportation; Ship environment

*Corresponding Author: adam.kustiadi@gmail.com 


\section{INTRODUCTION}

The cities of Jakarta, Surabaya, Bandung, and Bogor are estimated to have increased beef consumption by around 4 to $10 \mathrm{~kg} \mathrm{capita}^{-1}$ year $^{-1}$. However, this demand cannot be fulfilled by production from Java itself so that most of it is filled by imports of live cattle and frozen meat from Australia (Kusriatmi et al., 2014). Efforts have been made by the Indonesian government to improve the cattle supply chain. One unit of Camara Nusantara ship was launched in December 2015, and the number was increased to 6 units in early 2018. This cattle ship is expected to improve the cattle supply chain and shorten the distribution chain from producers to end consumers. However, there is still little information about the impact of ship transportation to cattle health.

The protection of animals during transport is an important concern of the European Commission (SCAHAW, 2002). Genswein et al., (2012) reported that the transportation activity such as transportation preparations, loading, shipping, and unloading of livestock using the ship and truck can generally cause stress. Few the main factors causing stress in livestock during transportation are microclimate factors (environment temperature, humidity, wind speed and temperature humidity index). Another factors such as handling livestock at the time loading/unloading, shipping time, vibration, transportation design, livestock density, quantity and quality of feed and drinking water availability.

Shifting one of the factors as mentioned earlier to the critical position of the conditions comfort can trigger a change in physiological status of livestock, which has a negative impact to livestock that is an increase in rectal temperature, heart rate and resporatory rate above normal (Purbowanti and Purnomoadi, 2005). Microclimate conditions such as environment temperature, humidity, wind speed, and THI can affect physiological parameters of cattle, especially on respiratory rate, heart rate, and rectal temperature (Suprayogi et $a l ., 2013)$. If it lasts for a long time, it can decrease the immune function that can cause death (Knowles, 1999).

Decreased immune function that cause death in livestock can cause high losses for cattle farmers in addition to cattle who die during transportation. When cattle arrived at the destination death can happened after a few days or few weeks after being raised by breeders. Sea transport studies from Australia to the Middle-East have reported that the main causes of cattle deaths were heat stroke, trauma and respiratory disease (Norris et al., 2003). In Sanggau (Pontianak), from the number of 121 heads Bali cattle shipments from Kupang, two cattle died during transportation and eight died during 2-30 days post transportation (Dinas Pertanian, Perikanan dan Peternakan, 2012). Although they have strived to minimize stress and the death of these cattle in the post transportation by improving the feeding management with ration balanced (balance of minerals, vitamins, protein, energy in the ration) as well as carried out injection with broad-spectrum antibiotics. Based on the description above, research has been done to find out physiological change of cattle during transportation using the Camara Nusantara 3 Ship from Kupang to Jakarta, by measuring several physiological parameters of cattle while on the Camara Nusantara 3 Ship.

\section{MATERIALS AND METHODS Site and time}

The research was conducted on the Camara Nusantara Ship in a route from the port of Tenau in Kupang to the Tanjung Priok Port in Jakarta. This study was conducted in December 2018 using 250 cattle in the ship. Cattle samples used were taken by purposive sampling total 12 heads of male Bali cattle with age of 1-2 years from different deck positions (4 cattles deck A, 4 cattles deck B, 4 cattles deck C). 


\section{Environmental conditions}

Observation of environmental conditions was carried out for three days (day 2, day 3, and day 4) on the Camara Nusantara ship 3. The observed environment parameters were wind speed, ambient temperature, humidity, and then the THI was calculated. Ambient temperature and air humidity on the ship were measured using humidity and temperature datalogger model Extech RHT20, while the shock and vibration in the ship are calculated using Gforce datalogger model Extech VB300. The wind speed was calculated every day using an anemometer at $09.00 \mathrm{AM}, 12.00$ noon, and 5.00 PM.

The livestock observed were divided into three decks, i.e., deck A, deck B, and deck C. From each deck, four different cattles were observed so that the total sample of cattles studied was 12 cattle (Fig. 1). THI is an index measuring the comfort level of livestock environment. According to Bulitta, Messmer, and Gebresenbet (2015), stress categories based on THI were $\leq 74$ for normal, $75-78$ for mild stress, $79-83$ for moderate stress, and $\geq 84$ for severe stress. THI Mathematical Model, according to Bulitta, Messmer and Gebresenbet (2015) is as follows:

$\mathrm{THI}=0.8 \mathrm{~T}_{\mathrm{ab}}+\mathrm{RH}\left(\mathrm{T}_{\mathrm{ab}}-14.4\right)+46.4$

Information :

THI = Temperature Humidity Index;

$\mathrm{T}_{\mathrm{ab}}=$ Ambient Temperature $\left({ }^{\circ} \mathrm{C}\right)$

$\mathrm{RH}=$ Relative Humidity (\%).

\section{Physiological parameters}

The physiological parameters measured during transport were rectal temperature, respiratory rate, heart rate, and oxygen saturation. Rectal temperature was measured using a digital thermometer Omron model MC-343F by raising the tail of the animal, and then the tip of the thermometer was inserted (1/3 part) into the rectum for about one min or until the numbers did not change and the indicator sounded.
Heart rate was calculated using a stethoscope by sticking it to the left chest of the cattle. When it was not possible, the heart rate was calculated by touching the coccygeal artery under the middle of the tail, about $10 \mathrm{~cm}$ from the anus, by hand to measure its pulse. The measurement was done for one min with three repetitions.

The respiratory rate was measured using a stethoscope, or by counting the flattening on the flank area, which was done for one min with three repetitions, then the average rate was taken. A stopwatch was used as a timepiece along with handheld tally counter to calculate the amount of surface movement of the rib-abdomen. One upward (inflated abdominal ribs) and downward movement (deflated abdominal ribs) were counted as one breath.

\section{Statistical analysis}

Data were analyzed using the IBM SPSS Statistics 20. Data were said to be significantly different at the probability level of $\mathrm{P}<0.05$. Experiment was conducted using a completely randomized design with a factorial arrangement between each deck (deck A, B, and C) compared to travel time (day 2, 3, and 4). Data were previously tested for normality and homogeneous data tests. The results of data analysis were presented as means and standard deviations. Data showing a lack of normality and homogeneity of variance were analyzed using a nonparametric analysis, i.e., the Kruskal-Wallis procedure. Parameters showing no significant difference were presented descriptively by looking at the relationship between travel time and each deck.

\section{RESULTS AND DISCUSSION Ship environment}

The results showed that deck $\mathrm{A}$ and deck $\mathrm{C}$ temperatures were higher than deck B. In general, deck A had a closed deck profile (from the front inlet to the rear outlet) with some ventilation and blower for air flow. The deck A position was at the bottom where the position was near the ship's engine and the blower was not fully active during 
the trip so that it was possible for an increase in temperature. While deck $\mathrm{C}$ had an open deck profile and got direct exposure to solar heat, so the environment temperature was quite high. The range of environment temperature in the ship during transportation was between $29.76^{\circ} \mathrm{C}-31.57^{\circ} \mathrm{C}$ with an average of $30.95 \pm 1.04^{\circ} \mathrm{C}$ (Table 1). From this parameter, it can be concluded that the temperature of the ship environment was quite hot and beyond the comfort zone of cattle. According to FAO (2011), normal environment temperature ranges from 18$24^{\circ} \mathrm{C}$, with critical temperatures occurring at $27^{\circ} \mathrm{C}$. EFSA (2004) further emphasized that in cattle transportation, the maximum temperature is $27^{\circ} \mathrm{C}$ with an air humidity of $80 \%$.

Based on research result, the environment temperature exceeded $29^{\circ} \mathrm{C}$ (Table 1), this means that cattle have experienced heat stress which was indicated by an increase in rectal temperature (Table 2). Following the opinion of Mahrunisa et al. (1999) that heat stress can occur if the environment temperature is higher than the comfort zone. High temperature and humidity in the ship paddock during transportation caused by lack of air circulation in ship deck. This is in accordance with Anton et al. (2016) that lack of air circulation can cause an increase in environment temperature and humidity. In this condition, the air circulation is not enough to help the livestock to reduce its body heat. The humidity in deck $\mathrm{A}$ and $\mathrm{C}$ was $68.26 \%$ and $69.73 \%$, respectively. These value were lower when compared to deck B of $72.81 \%$. The humidity in the deck $\mathrm{A}$ and deck $\mathrm{C}$ were lower because the environment temperature in both decks was higher than in deck B. The results show that the humidity in the ship was still considered as normal. Following the statement of Suprayogi et al. (2017) that the optimal cage air humidity for cattle is $60 \%-80 \%$. The microclimate conditions of the enclosure are presented in Table 1.

Based on the results of the study, the highest wind speed value was located in deck B. This is because deck B had open ventilation system with a ventilation size of $1.8 \mathrm{~m}$ with a deck height of $2.3 \mathrm{~m}$. Then, there was the loading and unloading gate for cattle so that the wind could enter from outside the ship. In deck $C$, the ventilation system was the same as in deck B, without much wind flowing into deck $B$ as there were no loading and unloading paths. The second-highest wind speed value was in deck A.

The air was from a ventilation system with a diameter of $70 \mathrm{~cm}$ and through a blower on the ventilation duct. THI is an interaction between temperature and humidity which indicates the comfort level of livestock. The THI value can be used to determine the level of comfort or stress experienced by the animal's body (Aju and Ihsan 2011).

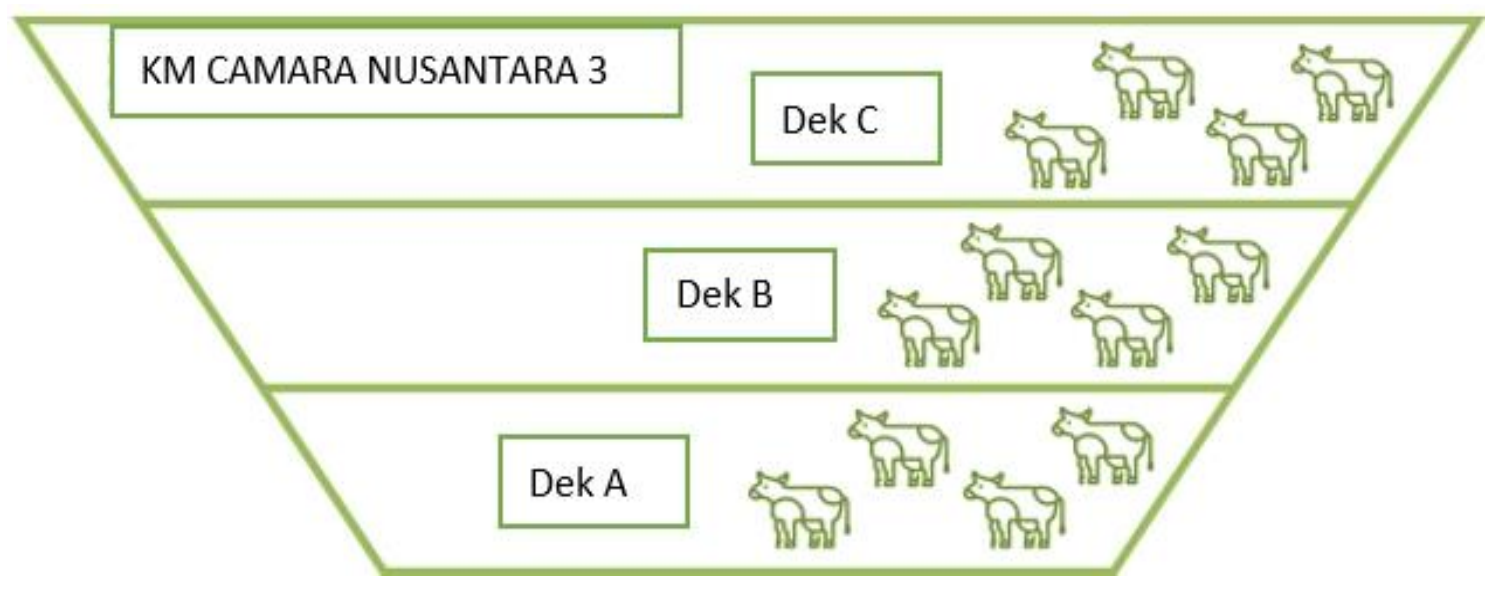

Figure 1. Illustration of cattle observation points on Camara Nusantara 3 ship 
Table 1. Condition of microclimate in the ship during the trip

\begin{tabular}{lccccc}
\hline \multicolumn{1}{c}{ Parameter } & Deck & Day 2 & Day 3 & Day 4 & Mean \\
\hline Environment & Deck A & $30.87 \pm 0.71$ & $31.57 \pm 1.01$ & $31.17 \pm 1.23$ & $31.21 \pm 0.92^{\mathrm{a}}$ \\
temperature & Deck B & $29.76 \pm 0.77$ & $30.85 \pm 0.90$ & $30.87 \pm 0.80$ & $30.49 \pm 0.90^{\mathrm{a}}$ \\
$\left({ }^{\circ} \mathrm{C}\right)$ & Deck C & $31.55 \pm 1.73$ & $31.35 \pm 1.35$ & $30.59 \pm 0.52$ & $31.16 \pm 1.21^{\mathrm{a}}$ \\
& Mean & $30.73 \pm 1.27$ & $31.26 \pm 1.01$ & $30.87 \pm 0.82$ & $30.95 \pm 1.04$ \\
\hline Humidity (\%) & Deck A & $72.66 \pm 3.15$ & $66.49 \pm 5.11$ & $65.64 \pm 3.90$ & $68.26 \pm 4.88$ \\
& Deck B & $79.29 \pm 3.31$ & $71.27 \pm 4.79$ & $67.89 \pm 2.69$ & $72.81 \pm 6.01$ \\
& Deck C & $71.86 \pm 8.29$ & $68.71 \pm 5.71$ & $68.63 \pm 3.31$ & $69.73 \pm 5.54$ \\
& Mean & $74.61 \pm 5.91^{\mathrm{b}}$ & $68.82 \pm 4.97^{\mathrm{a}}$ & $67.38 \pm 3.19^{\mathrm{a}}$ & $70.27 \pm 5.62$ \\
\hline THI & Deck A & $76.21 \pm 0.41$ & $74.95 \pm 0.21$ & $74.10 \pm 0.31$ & $75.08 \pm 0.96$ \\
& Deck B & $76.52 \pm 0.32$ & $75.43 \pm 0.65$ & $73.91 \pm 0.21$ & $75.29 \pm 1.19$ \\
& Deck C & $76.47 \pm 0.55$ & $74.75 \pm 1.09$ & $74.36 \pm 0.37$ & $75.19 \pm 1.16$ \\
Wind speed & Mean & $76.40 \pm 0.40^{\mathrm{c}}$ & $75.05 \pm 0.72^{\mathrm{b}}$ & $74.12 \pm 0.33^{\mathrm{a}}$ & $75.19 \pm 1.07$ \\
\hline knot) & Deck A & $1.33 \pm 1.15$ & $0.07 \pm 0.58$ & $0.10 \pm 0.10$ & $0.50 \pm 0.85^{\mathrm{a}}$ \\
& Deck B & $1.63 \pm 0.55$ & $2.43 \pm 0.31$ & $1.80 \pm 1.05$ & $1.96 \pm 0.71^{\mathrm{b}}$ \\
& Deck C & $0.20 \pm 0.35$ & $0.03 \pm 0.06$ & $0.10 \pm 0.10$ & $0.11 \pm 0.19^{\mathrm{a}}$ \\
& Mean & $1.06 \pm 0.93$ & $0.84 \pm 1.20$ & $0.67 \pm 1.00$ & $0.86 \pm 1.02$ \\
\hline
\end{tabular}

Numbers with different letters in the same column or row show significant differences $(\mathrm{P}<0.05)$.

The research results show the highest THI was in deck B, followed by deck A, and deck $\mathrm{C}$, with THI ranged from 73.91 to 76.52. The result shows that the value is in the category of mild stress for livestock, especially beef cattle. It can be seen that there was a significant difference $(\mathrm{P}<0.05)$ between the value of THI per day, the average value of THI decreased every day. The results showed that the THI value is directly proportional to the value of ambient temperature and humidity. This statement is following research by Astiningsih (2012), which states that the lower the THI value is, the lower the level of heat and humidity stress experienced by livestock.

\section{Physiological parameters and metabolism}

According to Borrel (2001), stress is a general condition in the form of threats to animals, when the body needs to adjust to the changes in physiological conditions and behavior until the adaptation process is achieved. Changes in physiological status (rectal temperature, respiratory rate, and heart rate) are presented in Table 2.

\section{Respiratory and heart rate}

Stressed animals will experience an increase in respiratory and heart rate, and at severe levels, there will be an increase in body temperature (Collier et al., 2007). The frequency of the heart rate reflects the strength and weakness of the heart's work in the body after transportation. Cattle on deck B had an average heart rate of $60.89 \pm 8.96$ times mins $^{-1}$, this value was higher when compared to deck A and $\mathrm{C}$ which was 54.99 \pm 7.56 times mins $^{-1}$ and $53.22 \pm 9.79$ times mins $^{-1}$, respectively. Statistically, the heart rate of cattle on deck B was not significantly different when compared to deck A and deck C. The frequency of heart rate in cattle during transportation was still within the normal range of normal cattle's heart rate which is 60-70 times min$^{-1}$ (Frandson 1992). An increase in heart rate can be caused by mild stress due to poor transportation activities such as poor handling by animal handlers, lack of feeding and drinking, and changes in environmental temperature during travel. The increased frequency of the heart rate is physiologically related to the increase in respiratory rate which causes increased activity of the breathing muscles thereby accelerating the distribution of heat to the edges of the skin to be released into the environment so that the body's balance is maintained. According to (Farooq et al., 2010) efforts made by cattle to maintain 
their body temperature under normal conditions due to transportation stress are by increasing the body's heat dissipation through breathing and increasing the heart rate. There was no significant difference $(\mathrm{P}>$ $0.05)$ on respiratory rate among cattle on different decks. However, there was an interaction between the difference in decks with the duration of the trip. The mean respiratory rate of cattle during transportation on deck $\mathrm{A}, \mathrm{B}$, and $\mathrm{C}$ was $25.77 \pm 6.93$ times $\min ^{-1}, 24.32 \pm 7.61$ times mins $^{-1}, \quad 23.11 \pm 5.06$ times mins $^{-1}$, respectively.

Table 2. Physiological parameters of cattles during shipment

\begin{tabular}{|c|c|c|c|c|c|}
\hline Parameter & Deck & Day 2 & Day 3 & Day 4 & Mean \\
\hline \multirow{4}{*}{$\begin{array}{l}\text { Rectal } \\
\text { temperature } \\
\left({ }^{\circ} \mathrm{C}\right)\end{array}$} & Deck A & $38.38 \pm 0.01$ & $37.99 \pm 0.51$ & $38.04 \pm 0.11$ & $38.14 \pm 0.33^{\mathrm{a}}$ \\
\hline & Deck B & $38.78 \pm 0.35$ & $38.68 \pm 0.30$ & $38.40 \pm 0.30$ & $38.62 \pm 0.33^{b}$ \\
\hline & Deck C & $38.33 \pm 0.27$ & $38.56 \pm 0.37$ & $38.41 \pm 0.33$ & $38.43 \pm 0.31^{\mathrm{ab}}$ \\
\hline & Mean & $38.49 \pm 0.32$ & $38.41 \pm 0.48$ & $38.28 \pm 0.30$ & $38.40 \pm 0.37$ \\
\hline \multirow{4}{*}{$\begin{array}{l}\text { Respiratory } \\
\text { rate }\left(\mathrm{min}^{-1}\right)\end{array}$} & Deck A & $30.00 \pm 6.93$ & $21.32 \pm 2.90$ & $25.97 \pm 8.34$ & $25.77 \pm 6.93^{\mathrm{a}}$ \\
\hline & Deck B & $32.00 \pm 5.65$ & $20.97 \pm 7.56$ & $20.00 \pm 2.20$ & $24.32 \pm 7.61^{\mathrm{a}}$ \\
\hline & Deck C & $18.00 \pm 2.31$ & $24.00 \pm 4.74$ & $27.32 \pm 2.58$ & $23.11 \pm 5.06^{\mathrm{a}}$ \\
\hline & Mean & $26.67 \pm 8.06$ & $22.10 \pm 5.10$ & $24.43 \pm 5.75$ & $24.40 \pm 6.53$ \\
\hline \multirow{4}{*}{$\begin{array}{l}\text { Heart rate } \\
\left(\min ^{-1}\right)\end{array}$} & Deck A & $54.00 \pm 5.16$ & $51.67 \pm 11.69$ & $59.33 \pm 2.31$ & $54.99 \pm 7.56^{\mathrm{a}}$ \\
\hline & Deck B & $59.00 \pm 8.87$ & $67.00 \pm 7.41$ & $56.67 \pm 9.08$ & $60.89 \pm 8.96^{\mathrm{a}}$ \\
\hline & Deck C & $56.00 \pm 9.79$ & $45.34 \pm 9.04$ & $58.34 \pm 6.74$ & $53.22 \pm 9.79^{a}$ \\
\hline & Mean & $56.33 \pm 7.71$ & $54.67 \pm 12.84$ & $58.11 \pm 6.14$ & $56.37 \pm 9.19$ \\
\hline
\end{tabular}

Numbers with different letters in the same column or row show significant differences $(\mathrm{P}<0.05)$.

The normal frequency of respiratory rate during transportation ranges from 15 to 30 times $\mathrm{min}^{-1}$ (Jackson and Cockroft, 2002). Therefore, cattle's heart rate and respiratory rate during the study were still in the normal range. This shows that the cattle were in a good environmental conditions.

\section{CONCLUSION}

The results showed that the activity of transporting Bali cattle from the Port of Tenau in Kupang to the Port of Tanjung Priok in Jakarta could affect physiological parameters and environmental conditions in the ship Camara Nusantara 3. It is proved by rectal temperature, THI, and wind speed. The rectal temperature and wind speed had significant results for a comparison between decks. The highest body temperature was on deck $B$ with a value of $30.49 \pm 0.90^{\circ} \mathrm{C}$, but the value was still within normal limits. The highest wind speed value was also found on deck B, which was $1.96 \pm 0.71$ knots.

The environment humidity and THI also had significant results according to the duration of the trip. On the second day, the environment humidity of the ship was 74.61 \pm 5.91 with a THI of $76.40 \pm 0.40$. There was a significant decrease in the second day for environment humidity, and then a significant decrease was also observed on the second and third day for the THI. These were included in the category of mild stress, but longer trip decreased the humidity and THI towards the standard value that can be accepted by cattle.

\section{REFERENCES}

Buckham Sporer, K. R., Weber, P. S. D., Burton, J. L., Earley, B., \& Crowe, M. A. (2008). Transportation of young beef bulls alters circulating physiological parameters that may be effective biomarkers of stress1. Journal of Animal Science, 86(6), 1325-1334. https://doi.org/10.2527/ jas.2007-0762

Bulitta, F. S., Aradom, S., \& Gebresenbet, G. (2015). Effect of transport time of up to 12 hours on welfare of cows and bulls. Journal of Service Science and Management, 08(02), 161-182. https: 
//doi.org/10.4236/jssm.2015.82019

Collier, R. J., Hall, L. W., Rungruang, S., \& Zimbleman, R. B. (2012). Quantifying heat stress and its impact on metabolism and performance. MidSouth Ruminant Nutrition Conference, 74-84.

Das, R., Sailo, L., Verma, N., Bharti, P., Saikia, J., Imtiwati, \& Kumar, R. (2016). Impact of heat stress on health and performance of dairy animals: A review. Veterinary World, 9(3), 260 268. https://doi.org/10.14202/vetworl d.2016.260-268

Dinas Pertanian Perikanan dan Peternakan Kabupaten Sanggau. (2012). Laporan perkembangan ternak tahun 2012.

EFSA. (2004). Opinion of the Scientific Panel on Animal Health and Welfare (AHAW) on a request from the Commission related to the welfare of animals during transport. EFSA Journal, 2(5), 1-36. https://doi.org/ 10.2903/j.efsa.2004.44

Farooq, U., Qayyum, A., Abdus Samad, H., \& Rashid Chaudhry, H. (2010). Physiological responses of cattle to heat stress zoonotic biohazardous bacteria view project. World Applied Sciences Journal, 8, 38-43.

FOA. (2011). Rural structures in the tropics. Design and development.

Frandson, R. (1992). Anatomi dan Fisiologi Ternak. Gadjah Mada University Press.

Jackson, P.G.G, \& Cockcroft, P. (2002). Clinical Examination of Farm Animals (Peter G.G. Jackson \& P. D. Cockcroft (eds.)). Blackwell Science Ltd. https://doi.org/10.1002/9780470 752425

Knowles, G. (1999). A review of the road transport of cattle. Veterinary Record, 144(8), 197-201. https://doi.org/10.11 36/vr.144.8.197

Krisnaningsih, A. T. N. (2012). The effect of roof materials and strain on broiler performance. Majalah Ilmiah Peternakan, 7(2).

Krisnaningsih, A. T. N., \& Ihsan, M. (2011).
Penampilan reproduksi sapi perah friesian holstein $(\mathrm{FH})$ pada berbagai paritas dan bulan laktasi di ketinggian tempat yang berbeda. TERNAK TROPIKA Journal of Tropical Animal Production, 12(2), 1-10.

Kusriatmi., Oktaviani, R., Syaukat, Y., \& Said, A. (2014). Analysis of the effects of beef import restrictions policy on beef self-sufficiency in Indonesia. Journal of the International Society for Southeast Asian Agricultural Sciences, 20(1), 115-130.

Mahrunnisa, S., Bilal, Q., \& Feroz, M. (1999). Review effect of temperature stress on nutrient utilization and different physiological function of ruminant animals. International Journal Agriculture and Biology, 1(3), 174-178.

Norris, R., Richards, R., Creeper, J., Jubb, T., Madin, B., \& Kerr, J. (2003). Cattle deaths during sea transport from Australia. Australian Veterinary Journal, 81(3), 156-161. https://doi.org/ 10.1111/j.1751-0813.2003.tb11079.x

Purbowati, E., \& Purnomoadi, A. (2005). Physiological responses of male local sheep at wide range liveweight after transported from up-land to low-land area. Prosiding Seminar Nasional Teknologi Peternakan Dan Veteriner, 539-544.

SCAHAW. (2002). The welfare of animals during transport (details for horses, pigs, sheep \& cattle).

Schwartzkopf-Genswein, K. S., Faucitano, L., Dadgar, S., Shand, P., González, L. A., \& Crowe, T. G. (2012). Road transport of cattle, swine and poultry in North America and its impact on animal welfare, carcass and meat quality: A review. Meat Science, 92(3), 227-243. https://doi.org/10.10 16/j.meatsci.2012.04.010

Suprayogi, A., Satrija, F., Tumbelaka, L. I. T., Indrawati, A., Purnawarman, T., Wijaya, A., Noviana, D., Ridwan, Y., \& Yudi. (2013). Pengelolaan 
Kesehatan Hewan dan Lingkungan. IPB Press.

Suprayogi, A., Alaydrussani, G., \& Ruhyana, A. Y. (2017). Hematology, heart rate, respiration rate, and body temperature values of lactating dairy cattle in Pangalengan. Jurnal Ilmu Pertanian Indonesia, 22(2), 127-132. https://doi.org/10.18343/jipi.22.2.127

Von Borell, E. H. (2001). The biology of stress and its application to livestock housing and transportation assessment. Journal of Animal Science, 79(E-Suppl), 260-267. https://doi.org/10.2527/jas2001.79ESupplE260x 